Document downloaded from:

http://hdl.handle.net/10251/156866

This paper must be cited as:

Vallespir, F.; Rodríguez, O.; Carcel, JA.; Rosselló, C.; Simal, S. (2019). Ultrasound assisted low-temperature drying of kiwifruit: Effects on drying kinetics, bioactive compounds and antioxidant activity. Journal of the Science of Food and Agriculture. 99(6):2901-2909. https://doi.org/10.1002/jsfa.9503

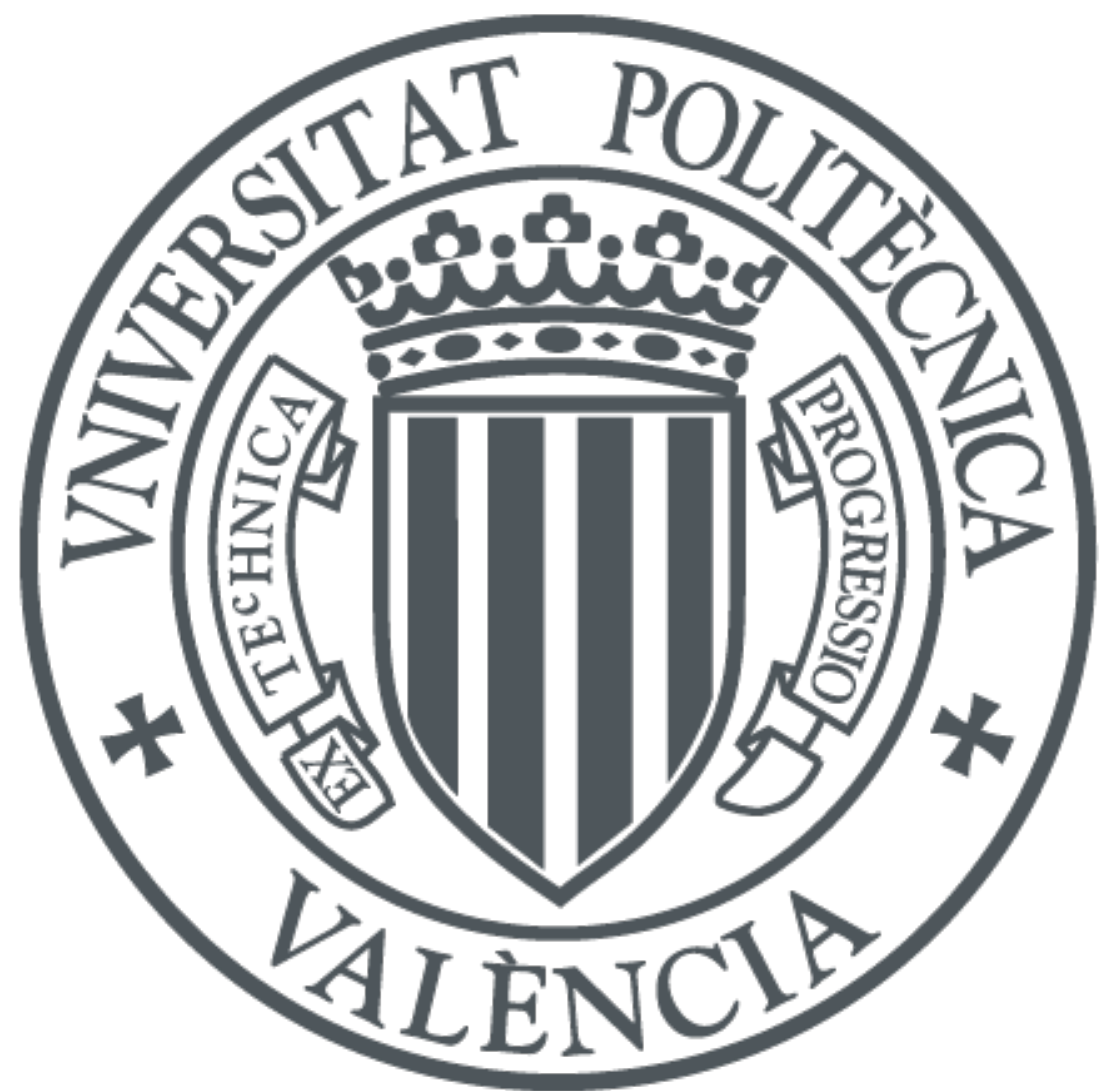

The final publication is available at

https://doi.org/10.1002/jsfa.9503

Copyright John Wiley \& Sons

Additional Information

"This is the peer reviewed version of the following article: Vallespir, Francisca, Oscar Rodríguez, Juan A Cárcel, Carmen Rosselló, and Susana Simal. 2019. Ultrasound Assisted Low-temperature Drying of Kiwifruit: Effects on Drying Kinetics, Bioactive Compounds and Antioxidant Activity. Journal of the Science of Food and Agriculture 99 (6). Wiley: 29019. doi:10.1002/jsfa.9503, which has been published in final form at https://doi.org/10.1002/jsfa.9503. This article may be used for non-commercial purposes in accordance with Wiley Terms and Conditions for Self-Archiving." 


\title{
Ultrasound assisted low-temperature drying of kiwifruit: Effects on drying kinetics, bioactive compounds and antioxidant activity
}

\author{
Francisca Vallespir, ${ }^{a}$ Óscar Rodríguez, ${ }^{a}$ Juan A Cárcel, ${ }^{b}$ Carmen Rossellóa \\ and Susana Simala ${ }^{*}$
}

\begin{abstract}
BACKGROUND: Low-temperature drying is considered to be a promising technique for food processing. It preserves thermolabile compounds and might be intensified by acoustic assistance. The effect of acoustic assistance $\left(20.5 \mathrm{~kW} \mathrm{~m}^{-3}\right)$ during low-temperature drying of kiwifruit (at 5,10 and $15^{\circ} \mathrm{C}$, and $1 \mathrm{~m} \mathrm{~s}^{-1}$ ) on drying kinetics, bioactive compounds (such as ascorbic acid, vitamin $\mathrm{E}$, and total polyphenols), and antioxidant activity was studied.

RESULTS: Drying time was shortened by $55-65 \%$ when using power ultrasound. A diffusion model was used to evaluate the drying kinetics. The effective diffusion coefficient increased by $154 \pm 30 \%$ and the external mass transfer coefficient increased by $158 \pm 66 \%$ when ultrasound was applied during drying, compared with drying without ultrasound application. With regard to bioactive compounds and antioxidant activity, although samples dried at $15^{\circ} \mathrm{C}$ presented significantly higher $(P<0.05)$ losses $\left(39-54 \%\right.$ and $57-69 \%$, respectively) than samples dried at $5^{\circ} \mathrm{C}(14-43 \%$ and $23-50 \%$, respectively) when ultrasound was not applied, the application of ultrasound during drying at $15^{\circ} \mathrm{C}$ significantly reduced $(P<0.05)$ those losses in all quality parameters $(15-47 \%$ and $47-58 \%$, respectively).
\end{abstract}

CONCLUSION: Overall, low-temperature drying of kiwifruit was enhanced by acoustic assistance preserving bioactive compounds and antioxidant activity, especially at $15^{\circ} \mathrm{C}$.

Keywords: kiwifruit; low-temperature drying; power ultrasound; bioactive compounds

\section{INTRODUCTION}

Kiwifruit crops and consumption have increased during recent decades, this fruit being appreciated by consumers in Western countries as an exotic food with health benefits mainly related to its antioxidant content. ${ }^{1}$ According to Du et al. ${ }^{2}$ kiwifruit is characterized byits high ascorbicacid and vitamin Econtentand other useful compounds such as carotenoids, chlorophylls, flavonoids, and minerals. The kiwi, like many other fruits, is highly perishable, so the development of optimal methods for its conservation is interesting, taking into account the fact that consumers demand minimally processed food products, with similar or equivalent nutritional and sensorial attributes to the fresh product and in compliance with food safety requirements. ${ }^{3}$

Convective drying is one of the most commonly used techniques for food preservation in industry. Drying improves food stability by reducing water activity, but it also promotes color and texture changes, shrinkage, and losses of different nutritional biocompounds. ${ }^{4}$ The extent of these changes, especially the losses of thermolabile biocompounds, is usually higher as both the drying temperature and the drying time increase. ${ }^{5}$

Low-temperature drying has thus been considered a promising technique for food preservation. Working at atmospheric pressure and using air at a temperature below standard room conditions and close to the water freezing point, and with low relative humidity (below $30 \%$ ), it has been found to preserve thermolabile compounds. ${ }^{6}$ For instance, according to Santacatalina et al. ${ }^{4}$ and Rodríguez etal., ${ }^{7}$ the losses of some biocompounds (total polyphenols and flavonoids) in Granny Smith apples during convective drying were $25 \%$ at $0^{\circ} \mathrm{C}, 28 \%$ at $10^{\circ} \mathrm{C}$, but $39 \%$ at $30^{\circ} \mathrm{C}$. Using this technique, a previous freezing process that would have had to be conducted during freeze-drying is not required ${ }^{4}$. Any extra quality loss caused by the ice crystal formation during freezing, as well as the high cost of freezing and vacuum, is therefore avoided.

However, by decreasing the air temperature, the mass transfer rate during drying also decreases, thus making low-temperature drying a time-consuming operation compared with conventional convective drying at high temperatures. Low-temperature drying is prone to be intensified by using complementary techniques to

\footnotetext{
* Correspondence to: S Simal, Department of Chemistry, University of the Balearic Islands, Ctra. Valldemossa km 7.5, 07122 Palma de Mallorca, Spain. E-mail: susana.simal@uib.es

a DepartmentofChemistry, UniversityoftheBalearic/slands, PalmadeMallorca, Spain

b ASPA Group, Food Technology Department, Polytechnic University of Valencia, Valencia, Spain
} 

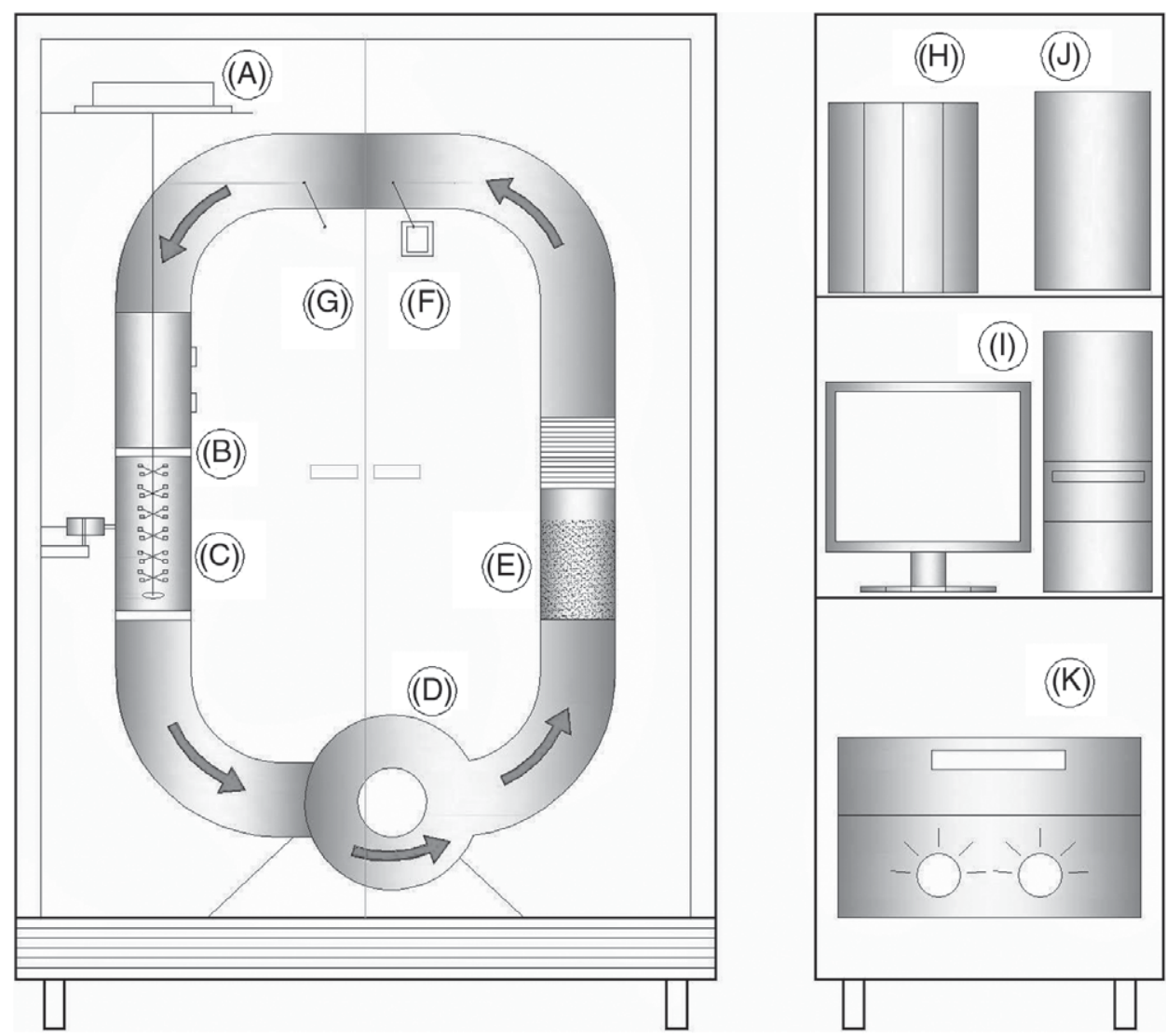

Figure 1. Schematic layout of the drying system. Arrows indicate the air blowing direction. A: Electronic scale; B: Drying chamber; C: Cylindrical radiator; D: Fan; E: Desiccant material; F: Humidity and temperature sensor; G: Flow sensor; H: Proportional-integral-derivative controller; I: Computer; J: Power ultrasonic transducer; K: Dynamic resonance controller and power amplifier.

enhance the water removal. ${ }^{8}$ One of these techniques is the use of power ultrasound, which has been applied during the convective drying of food products, proving its efficiency in shortening the drying time.${ }^{9,10}$ Moreover, according to García-Pérez et al. ${ }^{10}$ the development of a new family of power generators with extensive radiating surfaces has significantly contributed to the implementation at industrial scale of several applications in sectors such as the food industry, environment, and manufacturing. But, changes in biocompound content and antioxidant activity in food products during low-temperature drying, with and without ultrasound application, have barely been studied in the literature.

The aim of this study was therefore to analyze the influence of the drying temperature and acoustic assistance on the low-temperature drying kinetics, the ascorbic acid and vitamin E content, the total polyphenol content, and antioxidant activity of kiwifruit.

\section{MATERIALS AND METHODS}

\section{Sample preparation}

Kiwifruit (Actinidia deliciosa cultivar Hayward) were purchased in a local market in Spain. Toensure homogeneity of ripeness, they were selected with a total soluble solid content, measured as

${ }^{\circ} \mathrm{Bx}$, of $13.0 \pm 0.5^{\circ} \mathrm{Bx}$ and $\mathrm{pH}$ of $4.8 \pm 0.6$. The initial moisture content $\left(W_{0}\right)$, obtained by using the AOAC method $N^{\circ} 934.06,{ }^{11}$ was $5.8 \pm 0.4 \mathrm{~kg} \mathrm{~kg} \mathrm{d.m.}{ }^{-1}$ The fruits were peeled and the seedless and coreless pulp was shaped into parallelepipeds of $1.0 \times 1.0 \mathrm{x}$ $0.5 \mathrm{~cm}$.

\section{Acoustically assisted low-temperature drying experiments}

Drying experiments were carried out in a convective dryerwith air recirculation, air velocity, temperature control, and an ultrasonically activated drying chamber. The whole system is assembled into an industrial upright fridge ACRV-125-2 (Coreco, Spain). A schematic layout of the drying system is shown in Fig. 1.

Air flow is driven by a medium-pressure fan TD-800/200 ECOWATT (Soler \& Palau, Spain) and its temperature and flow rate is measured near the drying chamber by a flow sensor SS 20.250

(Schmidt, Germany). The air velocity (from 0.1 to $2.0 \mathrm{~ms}^{-1}$ ) is controlled by a proportional-integral-derivative algorithm, using an integrated intelligent real-time controller cRio-9092/3/4 (National Instruments, USA), which controls the fan speed, comparing the flow sensor signal to the set air velocity. The air temperature and relative humidity are measured in the air duct near to the drying chamber, using a DKK humidity and temperature sensor (Galltec+Mela, Germany). Tokeep the relative humidity low, the air is forced through a tray containing desiccant material, activated alumina pellets $1 / 4$ (Alphachem, Spain), which are periodically renewed.

A high-power ultrasonic application system is assembled, being connected to the convective dryer used as the drying chamber. It mainly consists of a cylindrical radiator (internal diameter $100 \mathrm{~mm}$, height $310 \mathrm{~mm}$, thickness $10 \mathrm{~mm}$ ) driven by a power ultrasonic transducer (frequency $21.9 \mathrm{kHz}$, impedance $369 \Omega$, power capacity $90 \mathrm{~W}$ ). An ultrasonic signal is generated and fitted to minimize the phase between electric voltage and intensity by a dynamic resonance controller APG-AC01 (Pusonics, Spain) and 
the power capacity is maintained through a power amplifier RMX 4050HD (QSC, USA). Finally, an impedance matching unit APG-AC01 (Pusonics, Spain) (impedance from 50 to $500 \Omega$ and inductance from 5 to $9 \mathrm{mH}$ ) is used tooptimize theultrasonicapplication electronically. The ultrasonic system provides an average sound pressure level in the drying chamber of $155 \mathrm{~dB}$.

Air flows through the cylindrical radiator, where the samples are placed on a hanging stainless steel tree. The determination of the drying kinetics was carried out by weighing the samples at

selected timesusing anelectronicscaleC-6200CBC(Cobos, Spain) connected to the Compact FieldPoint programable automation controller system (National Instruments, USA) by an interface RS-232. A weighing sequence was programmed in the controller to provide an accurate measurement. The fan was stopped and the ultrasonic system set to a minimumelectric voltage(ca.1.0V) by means of the RS-232 interface. The weight measurement was taken 20 times and the average was considered as the definitive figure. This was done in order to avoid the excess noise produced by the vibration of the cylindrical radiator.

An application was developed to provide overall control and monitoring of the drying process using LabVIEW 2013 programming code (National Instruments, USA). This application provides information on the airflow, air temperature, drying time, and sample weight during the drying process.

Two sets of drying experiments were carried out at temperatures of 5,10 , and $15^{\circ} \mathrm{C}$ air velocity of $1 \mathrm{~ms}^{-1}$ and relative air assistance (AIR experiments). In set 2, powerultrasound of 50W $\left(20.5 \mathrm{~kW} \mathrm{~m}^{-3}\right)$ was applied during the drying experiments (AIR $+$ $80 \%$ weight loss was achieved, which corresponded to a final moisture content of ca. $0.5 \mathrm{~kg} \mathrm{~kg} \mathrm{d.m.}{ }^{-1}$ Finally, each experiment was carried out intriplicate.

\section{Diffusion model}

The drying process was described by a mathematical modelconsidering the liquid diffusion as the main transport mechanism. Thus, the model consisted of the microscopic mass transfer balance combined with Fick's diffusion second law. Moreover, the process was considered to be isothermal. The governing equation for a differential element of the parallelepiped shape was formulated (Eqn(1)):

$$
\mathrm{D}_{\mathrm{e}} \frac{\left(\square^{2} \mathrm{~W}_{\mathrm{l}}\right.}{\square \mathrm{x}^{2}} \quad \frac{\square^{2} \mathrm{~W}_{\mathrm{l}}}{\square \mathrm{y}^{2}}+\frac{\left.\square^{2} \mathrm{~W}_{\mathrm{l}}\right)}{\square \mathrm{z}^{2}}=\frac{\square \mathrm{W}_{\mathrm{l}}}{\square t}
$$

The constant, isotropic, and effective diffusion coefficient $\left(D_{e}\right)$, representative of the global transport process, might include moleculardiffusion, liquid diffusion through the solid pores, vapor diffusionandallotherfactors that affectdrying characteristics. ${ }^{12}$ It was also assumed that no contraction or deformation of the solid particle occurred during the process. As an initial condition, the moisture distribution inside the solid was considered to be uniformat the beginning ofthe process(Eqn (2)). Asboundaryconditions, the moisture distribution symmetry (Eqn (3)) and the external mass transfer at the solid surface(Eqn(4)) were assumed.

$$
\begin{aligned}
& \longrightarrow \quad W_{\left.l_{(x, y, z)}\right|_{t=}}=W_{0}
\end{aligned}
$$

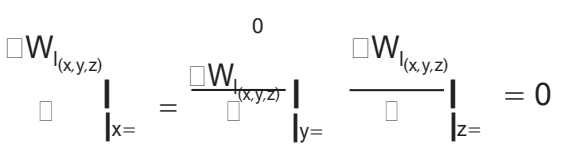

$$
\begin{aligned}
& -\mathrm{D}_{\mathrm{e}} \square \mathrm{dm} \frac{\square \mathrm{W}_{\mathrm{l}_{(x, y, z)}}}{\square \mathrm{X} \mathrm{l}_{\mathrm{l}} \mathrm{L}}=\mathrm{h}_{\mathrm{m}}\left(\square_{\mathrm{e}}-\square_{\infty}\right) \\
& -\mathrm{D}_{\mathrm{e}} \square_{\mathrm{dm}} \stackrel{\square \mathrm{W}_{\mathrm{I}_{(x, y, z)}}}{\square y \quad \mathrm{l}_{\mathrm{y}=\mathrm{L}}}=\mathrm{h}_{\mathrm{m}}\left(\square_{\mathrm{e}}-\square_{\infty}\right) \\
& -\left.\mathrm{D}_{\mathrm{e}} \square_{\mathrm{dm}} \frac{\square \mathrm{W}_{\mathrm{l}_{(x, y, z)}}}{\square \mathrm{Z}}\right|_{\mathrm{z}=\mathrm{L}}=\mathrm{h}_{\mathrm{m}}\left(\square_{\mathrm{e}}-\square \infty\right)
\end{aligned}
$$

The sorption isotherm for kiwifruit reported by Moraga et al. ${ }^{13}$ and the psychometric data were considered to complete the model.

COMSOL Multiphysics ${ }^{\circledR} \quad 5.1$ (COMSOL Inc., Sweden) software was used to solve the mathematical model, applying the finite elements method. The complete mesh consists of 9902 elements resulting in $2110^{\circ}$ of freedom. Matlab $2014 a^{\circledR}$ (The Mathworks, Inc., USA) software was used to develop the algorithm to identify both the effective diffusion $\left(D_{e}\right)$ and the external mass transfer $\left(h_{m}\right)$ coefficients by using the fminsearch function of Matlab, which uses the simplex search method described by Lagarias et al. ${ }^{14}$ The coefficients were identified from each drying curve through the minimization of the objective function (mean relative error, MRE) given by Eqn (5), which relates experimental and calculated average moisture content.

$$
\text { MRE }=\frac{100}{n} \sum_{i=1}^{n}\left|\frac{W_{\text {expi }_{i}}-W_{\text {exp }}}{W_{l}}\right|
$$

\section{Determination of ascorbic acid content}

The experimental procedure used to determine ascorbic acid content (AAC), as a reduced form of Vitamin $C$, in fresh and dried kiwifruit samples was the procedure proposed by Salkić, et al. ${ }^{15} \mathrm{~A}$ sample (ca. $1.0 \mathrm{~g}$ ) was homogenized with $10 \mathrm{~mL}$ of $0.056 \mathrm{~mol} \mathrm{~L}^{-1}$ sodium oxalate with an Ultra-Turrax T25 Digital (IKA, Germany) at $13000 \mathrm{rpm}$ for $30 \mathrm{~s}$. The extraction mixture was left standing for $5 \mathrm{~min}$. The homogenate was filtered and analiquot of $1.0 \mathrm{~mL}$ of the extract was diluted to $10 \mathrm{~mL}$ with $0.056 \mathrm{~mol} \mathrm{~L}^{-1}$ sodium oxalate. Absorbance readings were made in an UV-Vis spectrophotometer UV-2401 (Shimadzu, Japan)at $266 \mathrm{nmat}^{\circ} 5^{\circ} \mathrm{C}$, using $0.056 \mathrm{molL}^{-1}$ sodium oxalate as blank. Calibration curves were made using L-ascorbic acid as standard. The results were expressed as $\mathrm{mg}$ of L-ascorbic acid equivalent $\mathrm{g}$ d. $\mathrm{m}^{-1}$.

\section{Determination of vitamin E content}

Determination of the vitamin E content (VEC) in fresh and dried kiwifruit samples was carried out according to the methodology proposed by Fernandes et al. ${ }^{16}$ The sample (ca. $1.0 \mathrm{~g}$ ) was homogenized with $10 \mathrm{~mL}$ of distilled water with an Ultra-Turrax T25 Digital (IKA) at $13000 \mathrm{rpm}$ for $1 \mathrm{~min}$. Then, $1 \mathrm{~mL}$ of sodium hydroxide $0.5 \mathrm{~mol} \mathrm{~L}^{-1}$ was added to the sample and then heated at $70{ }^{\circ} \mathrm{C}$ for $30 \mathrm{~min}$ in a water bath. The mixture was cooled down using an ice bath, and $5 \mathrm{~mL}$ of hexane was added and the mixture was vigorously shaken for 1 min using a vortex. The supernatant (hexane phase) was collected and analyzed spectrophotometrically at $215 \mathrm{~nm}$ with a UV- Vis spectrophotometer UV-2401 (Shimadzu) using hexane as blank. Calibration curves were made using $\square$-tocopherol as standard. The results were expressed as $\mathrm{mg}$ of $\square$-tocopherol equivalent $g$ 
Total polyphenol content and antioxidant activity determinations

Methanol extracts from the kiwifruit samples were prepared according to the methodology described by Heredia and Cisneros-Zevallos. ${ }^{17}$ Samples wereaccurately weighed (ca. $1 \mathrm{~g}$ fresh samples or ca. $0.1 \mathrm{~g}$ dried samples) and $20 \mathrm{~mL}$ of methanol extraction solvent was added. The mixture was homogenized using a T25 Digital Ultra-Turrax (IKA) at $13000 \mathrm{rpm}$ for $1 \mathrm{~min}$ at $4{ }^{\circ} \mathrm{C}$ and the solution obtained was refrigerated overnight. Mixtures were centrifuged at $4000 \mathrm{rpm}$ for $10 \mathrm{~min}$ and then filtered. The extracts were refrigerated at $4{ }^{\circ} \mathrm{C}$ until analysis. At least four methanol extracts were prepared for each sample.

The total polyphenol content (TPC) was determined by means of the Folin- Ciocalteu assay according to Singleton and Rossi. ${ }^{18}$ The antioxidant activity (AA) was spectrophotometrically determined using the ferric reducing antioxidant power (FRAP), cupric reducing antioxidant capacity (CUPRAC), and 2 2'-azino-bis(3-ethylbenzothiazoline-6-sulfonic acid) (ABTS) methods as described by Benzie and Strain, ${ }^{19}$ Apak etal. ${ }^{20}$ and $\mathrm{Re}$ et al., ${ }^{21}$ respectively. Absorbance measurements were carried out

at $25{ }^{\circ} \mathrm{C}$ in a UV/Vis/NIR spectrophotometer Multiskan Spectrum (Thermo Scientific, Finland) at $745 \mathrm{~nm}$ (TPC), $593 \mathrm{~nm}$ (FRAP), $450 \mathrm{~nm}$ (CUPRAC), and $734 \mathrm{~nm}$ (ABTS). Absorbance measurements were correlated with standard curves $\left(0-250 \mathrm{mg} \mathrm{L}^{-1}\right.$ gallic acid for TPC and 0-400 $\mathrm{mg} \mathrm{L}^{-1}$ Trolox for AA). The results were expressed as $\mathrm{mg}$ of gallic acid equivalent $\mathrm{g} \mathrm{d} . \mathrm{m}^{-1}$. for the TPC, while the AA was expressed as mg of Trolox equivalent $\mathrm{g} \mathrm{d} . \mathrm{m}^{-1}$.

\section{Statistical analyses}

All quality determinations were carried out in triplicate and results were expressed as the percentage loss(\%)ofthequality attribute using the figures determined for the fresh sample as reference (Eqn (6)):

$$
\operatorname{Loss}(\%)=\frac{\text { [Fresh }- \text { Dried }}{\text { Fresh }} \times 100
$$

Data were averaged from replicates and reported as an average figure \pm standard deviation. An analysis of variance (ANOVA) was applied to analyze the effects of both the drying temperature and the acoustic assistance during drying on the ascorbic acid and vitamin E contents, the total polyphenol content, and the antioxidant activity. Means were compared using Tukey's test at $P<0.05$. Statistical analyses were carried out using Language and Environment for Statistical Computing R (R Core Team, Austria).

The percentage of explained variance (var) was also used to evaluate further the accuracy of the simulation obtained (Eqn (7)):

$$
\operatorname{var}=1-\frac{S_{y x}}{S_{y}} \times 100
$$

\section{RESULTS ANDDISCUSSION}

\section{Drying kinetics}

Figure 2 shows the experimental drying curves (dots) for the different drying temperatures $\left(5,10\right.$, and $\left.15^{\circ} \mathrm{C}\right)$ without (AIR) and with an acousticassistance of $20.5 \mathrm{~kW} \mathrm{~m}^{-3}$ (AIR + US). Although low-temperature drying is a time-demanding process, the use of acoustic energy promoted a remarkable reduction of the drying time. As an example, to reach a moisture content of $0.65 \pm 0.03 \mathrm{~kg} \mathrm{~kg} \mathrm{~d} . \mathrm{m} .^{-1}$, the drying time for the AIR samples dried at 5,10 and $15^{\circ} \mathrm{C}$ were of ca. 60,34 , and $19 \mathrm{~h}$, respectively, whereas when ultrasound was applied (AIR + US), the drying time

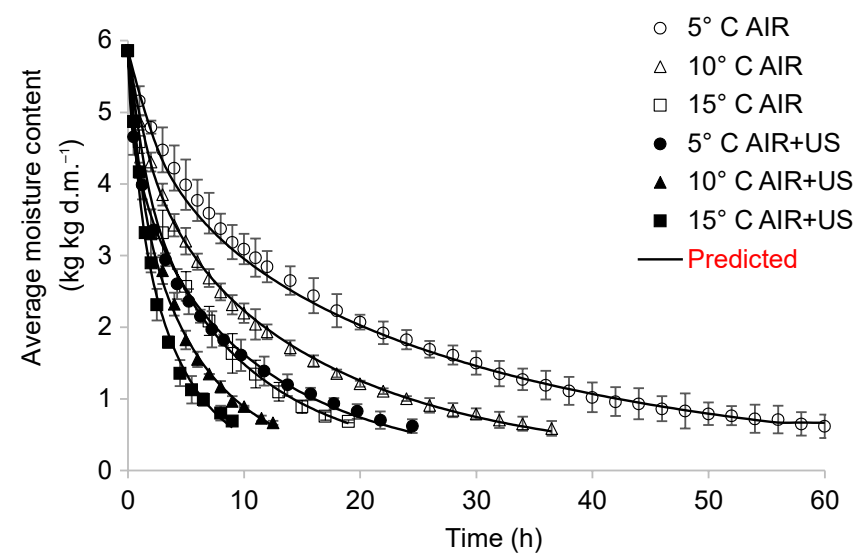

Figure 2. Experimental and predicted drying kinetics of kiwifruit without (AIR) and with $20.5 \mathrm{kWm}^{-3}$ of acoustic assistance (AIR + US) at 5,10 , and $15^{\circ} \mathrm{C}$. Average values \pm standard deviations.

decreased by $62 \%, 65 \%$, and $55 \%$ at 5,10 , and $15^{\circ} \mathrm{C}$, respectively. Santacatalina etal. ${ }^{22}$ also studied the influence of acoustic assistance during the low-temperature drying at $1 \mathrm{~m} \mathrm{~s}^{-1}$ of eggplant cubes. These authors reported reductions in the drying time of $80 \%$ and $58 \%$ when anacousticassistance of $20.5 \mathrm{~kW} \mathrm{~m}^{-3}$ was applied at drying temperatures of 0 and $10^{\circ} \mathrm{C}$, respectively. Similarly, in thelow-temperature drying ofapplecubes from 0 to $10^{\circ} \mathrm{C}$ $\left(2 \mathrm{~ms}^{-1}\right)$, Santacatalina et al. ${ }^{4}$ observed that the acousticassistance $\left(20.5 \mathrm{~kW} \mathrm{~m}^{-3}\right)$ increased the drying rate of apples at every drying temperature tested. In this case, the reduction of the drying time promoted by ultrasound application was similar (60\%) in the experiments carried out at 0,5 , and $10^{\circ} \mathrm{C}$.

\section{Diffusion model}

As described above, the diffusion model was designed for a parallelepiped.Byminimizing the differences between the experimental drying curves and the calculated ones, the effective diffusion coefficient $D_{e}$ and the external mass transfer coefficient $h_{m}$, were simultaneously determined for each experiment. Results are presented in Table 1, together with the average MRE and var, obtained by comparing the experimental and simulated drying curves.

The identified $D_{e}$ in the AIR experiments ranged from $1.37\left(5^{\circ} \mathrm{C}\right)$ to $4.30 \times 10^{-11} \mathrm{~m}^{2} \mathrm{~s}^{-1}\left(15^{\circ} \mathrm{C}\right)$, but in the AIR + US experiments this coefficient ranged from $3.67\left(5^{\circ} \mathrm{C}\right)$ to $9.45 \times 10^{-11} \mathrm{~m}^{2} \mathrm{~s}^{-1}\left(15^{\circ} \mathrm{C}\right)$. These figures were within the range of those observed by Santacatalina et al. ${ }^{4}$ in the low-temperature drying of apple $\left(2 \mathrm{~m} \mathrm{~s}^{-1}\right)$. Santacatalina et al. ${ }^{4}$ reported $\mathrm{D}_{\mathrm{e}}$ figures from $3.3\left(0^{\circ} \mathrm{C}\right)$ to $8.8 \times$ $10^{-11} \mathrm{~m}^{2} \mathrm{~s}^{-1}\left(10^{\circ} \mathrm{C}\right)$, when drying was carried out without acoustic assistance, and from $8.6\left(0^{\circ} \mathrm{C}\right)$ to $22.3 \times 10^{-11} \mathrm{~m}^{2} \mathrm{~s}^{-1}\left(10^{\circ} \mathrm{C}\right)$, when an acoustic power of $20.5 \mathrm{Wm}^{-3}$ was applied. Higher figures were reported byDarıcıand Sen ${ }^{23}$ in the hot-airdrying of kiwifruitslices of $4 \mathrm{~mm}\left(2.3-7.0 \times 10^{-10} \mathrm{~m}^{2} \mathrm{~s}^{-1}\right)$ and $6 \mathrm{~mm}$ thickness $(2.8-5.9 \times$ $\left.10^{-10} \mathrm{~m}^{2} \mathrm{~s}^{-1}\right)$ dried between 50 and $80^{\circ} \mathrm{C}$ and with an air velocity of $0.5 \mathrm{~m} \mathrm{~s}^{-1}$. Thus, ten times higher effective diffusion coefficients were obtained at hot air drying, probably due to faster water diffusion inside the solid matrix at higher temperatures.

As expected, the higher the drying temperature, the higher the effective diffusion coefficient. The identified effective diffusion coefficientincreased by $214 \%$ and $157 \%$ in the AIR and AIR + US experiments, respectively, when the temperature was increased from 5 to $15^{\circ} \mathrm{C}$. The effective diffusion coefficient increment was higher in AIR experiments than in AIR + US experiments as was also reported by Santacatalina et al. ${ }^{4}$ (167\% and $160 \%$ in AIR and 
Table 1. Identified effective diffusion $\left(D_{e}\right)$ and external mass transfer $\left(h_{m}\right)$ coefficients together with the MRE and var, for each set of drying experiments without (AIR) and with $20.5 \mathrm{~kW} \mathrm{~m}^{-3}$ of acoustic assistance (AIR + US) at different temperatures

\begin{tabular}{|c|c|c|c|c|c|c|c|c|c|c|c|c|}
\hline \multirow{3}{*}{$\begin{array}{l}\mathrm{T}\left({ }^{\circ} \mathrm{C}\right) \\
\mathrm{D}_{\mathrm{e}} \cdot 10^{11}\left(\mathrm{~m}^{2} \mathrm{~s}^{-1}\right)\end{array}$} & \multicolumn{6}{|c|}{ AIR } & \multicolumn{6}{|c|}{ AIR + US } \\
\hline & \multicolumn{2}{|c|}{5} & \multicolumn{2}{|c|}{10} & \multicolumn{2}{|c|}{15} & \multicolumn{2}{|c|}{5} & \multicolumn{2}{|c|}{10} & \multicolumn{2}{|c|}{15} \\
\hline & 1.37 & \pm 0.05 & 2.37 & \pm 0.11 & 4.30 & \pm 0.09 & 3.67 & \pm 0.11 & 6.52 & \pm 0.52 & 9.45 & \pm 0.48 \\
\hline $\mathrm{h}_{\mathrm{m}} \cdot 10^{5}\left(\mathrm{~kg}\right.$ water $\left.\mathrm{m}^{-2} \mathrm{~s}^{-1}\right)$ & 3.86 & \pm 0.11 & 6.40 & \pm 0.06 & 9.36 & \pm 0.17 & 12.76 & \pm 0.59 & 15.29 & \pm 0.42 & 19.01 & \pm 0.19 \\
\hline MRE (\%) & 3.2 & \pm 1.2 & 2.3 & \pm 0.9 & 2.2 & \pm 0.7 & 3.7 & \pm 0.5 & 2.7 & \pm 1.3 & 5.5 & \pm 0.6 \\
\hline $\operatorname{var}(\%)$ & 99.4 & \pm 0.1 & 99.8 & \pm 0.2 & 99.9 & \pm 0.1 & 99.6 & \pm 0.1 & 99.8 & \pm 0.1 & 99.4 & \pm 0.1 \\
\hline
\end{tabular}

AIR + US experiments, respectively) and by Santacatalina et al. ${ }^{22}$ (105\% and $33 \%$ in AIR and AIR + US experiments, respectively) when increasing drying temperature from 0 to $10^{\circ} \mathrm{C}$. Thus, it seems that temperature had less influence in the AIR + US experiments than in the AIR experiments.

Moreover, AIR + US samples exhibited higher $D_{e}$ coefficients compared with AIR samples, as a consequence of the acoustic assistance and its contribution to the reduction of the internal mass transfer resistance. As was pointed out in other researchers' work, the effective diffusion coefficient increment in AIR + US experiments is mainly linked to mechanical effects provoked in the material. Ultrasound generates a series of rapid and cyclic compressions and expansions of the material, which can be compared to a sponge being squeezed and released repeatedly, thus improving the water diffusion in the solid. ${ }^{6}$ The $D_{\epsilon}$ coefficient increment was $168 \%$ at $5{ }^{\circ} \mathrm{C}$; meanwhile, at $15^{\circ} \mathrm{C}$, it was lower $(120 \%)$. Thus, the increment was higher at the lowest temperature. Similar behavior was reported by Santacatalina et al. ${ }^{4}$ and by Santacatalina et $a l .{ }^{22}$ when ultrasound was applied in apple ( $148 \%$ and $136 \%$ of $D_{e}$ increment at 0 and $10^{\circ} \mathrm{C}$, respectively) and eggplant $\left(389 \%\right.$ and $264 \%$ of $D_{e}$ increment at 0 and $10 \mathrm{C}$, respectively) low-temperature drying. It seems that ultrasound mechanical effects were more effective at lower temperatures, as García-Pérez et al. ${ }^{24}$ and Gamboa-Santos et al. ${ }^{25}$ reported in hot air drying of carrot $\left(\right.$ at $\left.30-70^{\circ} \mathrm{C}\right)$ and strawberry (at $\left.40-70^{\circ} \mathrm{C}\right)$, respectively. These authors also observed an increment of the ultrasound influence on the effective diffusion coefficient as the temperature decreased. In fact, at the highest drying temperature $\left(70^{\circ} \mathrm{C}\right)$ no significant differences in $D_{e}$ were observed between AIR and AIR + US experiments. It seems that ultrasound application introduces a given amount of energy into the solid thus affecting water mobility. As temperature increases, the mobility linked to temperature increases and the relative influence of ultrasound energy on the internal resistance diminishes.

The effective diffusion coefficient temperature dependency was satisfactorily correlated to an Arrhenius type equation (Eqn (8)) in the AIR and AIR + US experiments as was also done in low-temperature drying by Ozuna etal. ${ }^{6}$ The Arrhenius linear correlation of $D_{e}$ is represented in Fig. 3.

$$
\left.D_{e}=D_{o} \exp ^{[}-\frac{E_{a}}{R(T+273.15)}\right]
$$

Correlation coefficients close to the unit were obtained in both cases (0.999 and 0.987 in AIR and AIR + US experiments, respectively). Thus, the adjustment to the Arrhenius-type equation was satisfactory. The $D_{0}$ coefficient obtained was significantly lower (99\% of decrease) in the AIR + US experiments $\left(27 \pm 2 \mathrm{~m}^{2} \mathrm{~s}^{-1}\right)$ than
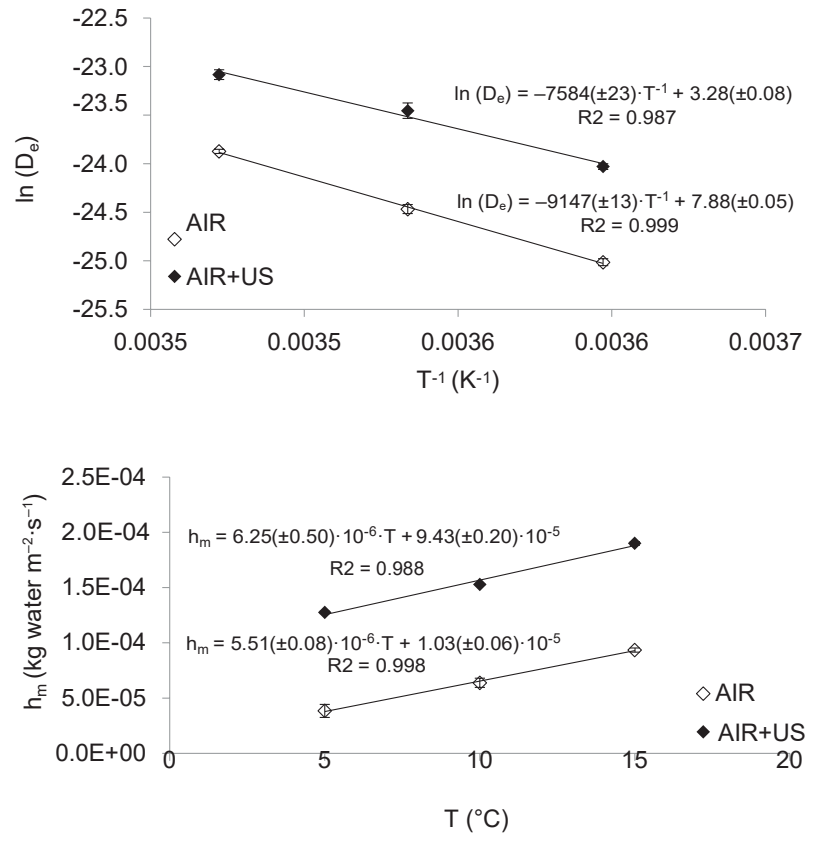

Figure 3. Influence of drying air temperature on the average effective diffusion and external mass transfer coefficients identified for kiwifruit drying without (AIR) and with $20.5 \mathrm{kWm}^{-3}$ of acoustic assistance (AIR + US) at 5,10 , and $15^{\circ} \mathrm{C}$. Average values \pm standard deviations.

in the AIR experiments $\left(2636 \pm 132 \mathrm{~m}^{2} \mathrm{~s}^{-1}\right)$. Moreover, the estimated activation energy $E_{a}$ for AIR and AIR + US experiments was of $77.0 \pm 0.1$ and $63.8 \pm 0.2 \mathrm{~kJ} \mathrm{~mol}^{-1}$. These figures were significantly different $(P<0.05)$ between them, the Ea for the AIR + US experiments being $17 \%$ lower than that for the AIR experiments. Similar results were also reported by Gamboa-Santos et al. ${ }^{25}$ in strawberry drying (at $40-70^{\circ} \mathrm{C}$ and $2 \mathrm{~ms}^{-1}$ ) and by Do Nascimento etal. ${ }^{26}$ in passion-fruit peel drying (at $40-70^{\circ} \mathrm{C}$ and $1 \mathrm{~ms}^{-1}$ ). According to these authors, the influence of the temperature on the $D_{e}$ seemed to be more limited when ultrasound was applied. The application of ultrasound provided additional energy with which to facilitate the drying, the relative importance of which decreased as the drying temperature rose. The mechanical force given by the acoustic waves can create microscopic channels due to the 'sponge effect', which allows an easier inner water movement without significant overheating of the material being dried taking place. ${ }^{27}$

As can beseen in Table 1, the externalmass transfercoefficient $\mathrm{h}_{\mathrm{m}}$ was affected by both the drying temperature and the acoustic assistance. The identified $h_{m}$ figures ranged from $3.86 \times 10^{-5} \mathrm{~kg}$ waterm ${ }^{-2} \mathrm{~s}^{-1}$ at $5^{\circ} \mathrm{C}(\mathrm{AIR})$ to $19.01 \times 10^{-5} \mathrm{~kg}$ waterm ${ }^{-2} \mathrm{~s}^{-1}$ at 
$15^{\circ} \mathrm{C}$ (AIR + US). In low-temperature drying of apples at $2 \mathrm{~m} \mathrm{~s}^{-1}$ of air velocity and temperatures of 0 and $10^{\circ} \mathrm{C}^{4}$ and $10^{\circ} \mathrm{C}^{28}$, with and without ultrasound application, higher $\mathrm{h}_{\mathrm{m}}$ figures were reported: $2.7-9.1 \times 10^{-4}$ and $4.3-10 \times 10^{-4} \mathrm{~kg}^{-1}$ water $\mathrm{m}^{-2} \mathrm{~s}^{-1}$, respectively, probably due to higher air velocity figures than in the present study $\left(1 \mathrm{~m} \mathrm{~s}^{-1}\right)$. Thus, external resistance to moisture removal was significantly different at $2 \mathrm{~m} \mathrm{~s}^{-1}$ of air velocity than $1 \mathrm{~ms}^{-1}$ of air velocity.

The increase in the drying temperature from 5 to $15^{\circ} \mathrm{C}$ caused an increase of $h_{m}$ by $142 \%$ in AIR experiments and by $49 \%$ in AIR + US experiments. Thus, at higher temperatures, an increase in the external mass transfer coefficient was observed, being higher in AIR experiments than in AIR + US experiments. Santacatalina et al. ${ }^{22}$ also observed a higher external mass transfer coefficient increase in AIR experiments $(63 \%)$ than in AIR + US experiments $(30 \%)$. The AIR experiments therefore presented a more important temperature effect than AIR + US experiments.

Acousticassistanceinduced a decrease in theexternal resistance to the masstransferduetothe pressurevariationsatthesolid/gas interfaces, and so it increased the surface moisture evaporation rate. ${ }^{7}$ The sample vibrates in a microscale due to the ultrasound effects, which might also affect the external resistance. Thus, the acoustic assistance increased the external mass transfer coefficient $\mathrm{h}_{\mathrm{m}}$. Similarly to as was observed in the effective diffusion coefficient, this effect was more evident at $5{ }^{\circ} \mathrm{C}$ with an increase of $231 \%$ in this coefficient, while at $15^{\circ} \mathrm{C}$, the increment was $103 \%$, probably due to the relative amount ofthermal and acousticenergy. The effect of acoustic assistance on the external mass transfer coefficient was also studied during acoustically assisted $\left(20.5 \mathrm{~kW} \mathrm{~m}^{-3}\right)$ low-temperature drying, at an air velocity of $1 \mathrm{~m} \mathrm{~s}^{-1}$, of eggplant by Santacatalina etal., ${ }^{22}$ respectively. In this study, higher increments of external mass transfer coefficient were also observed at $0^{\circ} \mathrm{C}(383 \%)$ than at $10^{\circ} \mathrm{C}(262 \%)$ when applying ultrasound.

The temperature dependency of the external mass transfer coefficient was linearly correlated (Eqn (9)) in AIR and AIR + US experiments. This is represented in Fig. 3 .

$$
\mathrm{h}_{m}=h_{k} \cdot T+h_{\mathrm{o}}
$$

The adjustment to a linear type equation was suitable because in both cases correlation coefficients close to the unitwere obtained (0.998 and 0.988 in AIR and AIR + US experiments, respectively).

The $h_{0}$ coefficient significantly increased (by $811 \%$ ) in AIR + US experiments $\left(9.43 \pm 0.20 \times 10^{-5} \mathrm{~kg} \mathrm{~m}^{-2} \mathrm{~s}^{-1}\right)$ compared with AIR experiments $\left(1.03 \pm 0.06 \times 10^{-5} \mathrm{~kg} \mathrm{~m}^{-2} \mathrm{~s}^{-1}\right)$. Moreover, in AIR + US experiments, a significantly higher $(14 \%) h_{k}$ coefficient was obtained $\left(6.25 \pm 0.5 \times 10^{-6} \mathrm{kgm}^{-2} \mathrm{~s}^{-1}{ }^{\circ} \mathrm{C}^{-1}\right)$ than in AIR experiments $\left(5.51 \pm 0.08 \times 10^{-6} \mathrm{kgm}^{-2} \mathrm{~s}^{-1}{ }^{\circ} \mathrm{C}^{-1}\right)$. Thus, whenultrasound was applied, the surface moisture evaporation rate was enhanced and the external mass transfer coefficient increased. Not only was the external mass transfer coefficient in AIR + US experiments higher but it was also more affected by the temperature factor.

The drying curves were predicted by using the figures for $D_{e}$ and $h_{m}$ coefficients corresponding to Arrhenius (Eqn (8)) and linear (Eqn (9)) correlations, respectively. They are represented in Fig. 2 by continuing lines. The simulation was evaluated mathematically using the MRE (\%) and var (\%) figures, included in Table 1. As the MRE was lower than $6 \%$ and var was higher than $99 \%$ in all experiments, itcould beconcludedfrom Fig. 2andTable 1 that the drying curves of kiwifruitdried at 5,10 and $15^{\circ} \mathrm{C}$ without and with acoustic assistance $\left(20.5 \mathrm{~kW} \mathrm{~m}^{-3}\right)$ could be satisfactorily simulated by using the proposed model.
The use of the proposed model allowed us to evaluate the influence of ultrasound application on both the internal and external mass transfer resistance. From the figures obtained for the diffusion coefficient and the mass transfer coefficient, it could be concluded that the use of acoustic energy contributed to the acceleration of the drying process, not only decreasing the external resistance but also increasing the water mobility inside the food. The mechanical vibration produced by the ultrasound application affected both the internal resistance to the mass transport, by successive compressions and expansions of the material ('sponge effect'), and the external resistance to the mass transport due to the reduction of the boundary layer, which eased the vapor transfer rate from the solid surface to the drying air. ${ }^{29}$ Thesum ofbotheffectsled toan improvementinthe water release during the drying process.

\section{Bioactive compounds determinations}

To determine the influence of the drying temperature and the ultrasound application during drying on the main bioactive compounds of kiwifruit, ascorbic acid content (AAC), vitamin E content (VEC), and total polyphenol content (TPC) were determined before and after drying.

In the fresh sample, the AAC and VEC were of $4.4 \pm 0.2 \mathrm{mg}$ L-ascorbic acid equivalent $\mathrm{g} \mathrm{d} . \mathrm{m}^{-1}$ and $0.098 \pm 0.002 \mathrm{mg}$

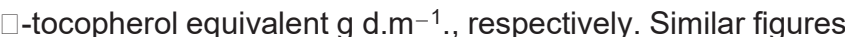
for AAC and VEC in fresh Zespriß ${ }^{\circledR}$ Sweet Green Kiwifruit were reported by Sivakumaran et al. ${ }^{30}(4.3-7.6 \mathrm{mg}$ L-ascorbic acid equivalent $\mathrm{g} \mathrm{d.m.}{ }^{-1}$ and $0.059-0.114 \mathrm{mg} \square$-tocopherol equivalent $\mathrm{g} \mathrm{d.m.} .^{-1}$, respectively). The TPC of fresh sample was of $10.0 \pm 0.4 \mathrm{mg}$ gallic acid equivalent $/ \mathrm{g} \mathrm{d} . \mathrm{m}^{-1}{ }^{-1}$, which was in the range of the TPC proposed by Pal et al. ${ }^{31}$ for fresh Hayward cultivar kiwifruit in three different fruit-harvesting months $(7.9-11.3 \mathrm{mg}$ gallic acid equivalent $\mathrm{g}$ d.m. ${ }^{-1}$ ).

Figure 4 shows the AAC, VEC, and TPC losses (\%) of kiwifruit samples after drying at 5,10 , and $15^{\circ} \mathrm{C}$ without (AIR) and with ultrasound application (AIR + US), compared with the fresh sample. Drying without ultrasound application (AIR) at 5, 10, and $15^{\circ} \mathrm{C}$ promoted AAC, VEC, and TPC losses of $14-26 \%, 28-54 \%$, and $14-39 \%$, respectively. Thus, as can be observed in Fig. 4, VEC losses were higher than AAC losses in dried kiwifruit at 5, 10 and $15^{\circ} \mathrm{C}$. As reported by Ball, ${ }^{32}$ the main factors contributing to vitamin losses during processing are light, metal ions, and oxidation, due to air exposure that occurs during convective drying. Vita$\min E$ is fat-soluble and is represented by four tocopherols and four tocotrienols. ${ }^{32}$ Ascorbic acid is water-soluble and is a generic descriptorforall compounds exhibiting qualitatively the biological activity of ascorbic acid. ${ }^{32}$ Thermal stability of vitamin E depends on processing time and conditions; meanwhile, ascorbic acid is stableonexposure toairand daylightatnormal room temperature for long periods of time. ${ }^{32}$ Itseems, therefore, that ascorbic acid was more stable than vitamin $E$ to air exposure during kiwifruit drying at 5,10 , and $15^{\circ} \mathrm{C}$.

No studies of quality changes in kiwifruit dried at low temperatures have been found in the literature, so we have referred instead to those regarding changes in the quality of kiwifruit as a consequence of drying with hot air. Higher AAC losses (49-88\%) were observed after the convective drying of kiwifruit slices at $35-65^{\circ} \mathrm{C}$, compared to the fresh sample. ${ }^{33}$ Nothing has been found in the literature about VEC changes after kiwifruit drying, either. Regarding TPC losses, similar figures (11-49\%) were observed by Izli et al. ${ }^{34}$

when kiwifruitslices were dried at 60,70 , and $80^{\circ} \mathrm{C}$ and $1.5 \mathrm{~ms}^{-1}$. 

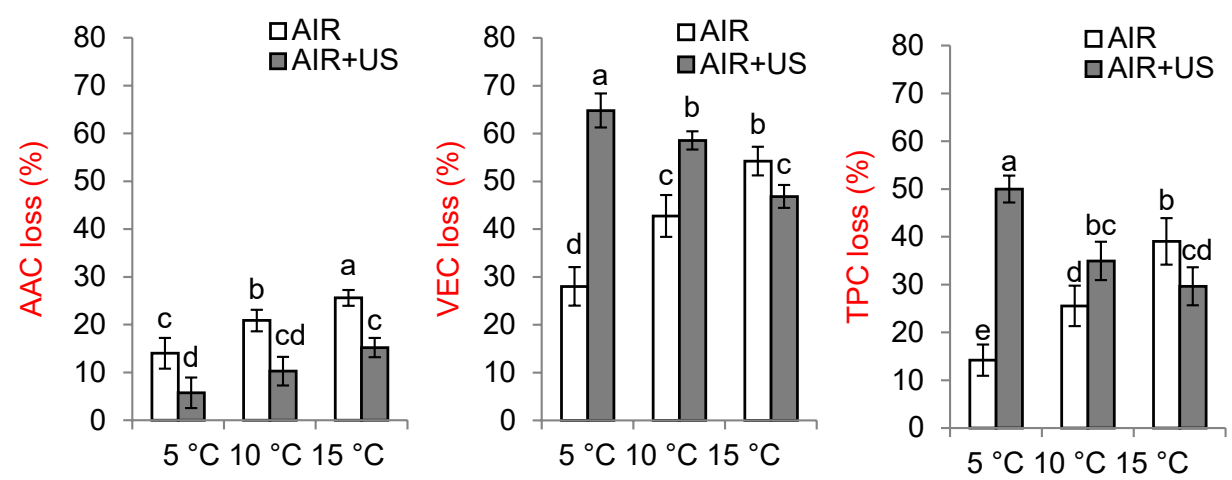

Figure 4. Kiwifruitlosses (\%) of ascorbic acid content(AAC), vitamin Econtent(VEC)and total polyphenol content(TPC)afterdrying at 5,10 and $15^{\circ} \mathrm{C}$ without (AIR, white bars) and with $20.5 \mathrm{~kW} \mathrm{~m}^{-3}$ of acoustic assistance (AIR + US, grey bars). Average values \pm standard deviations. Means with different letters for AAC, VEC or TPC losses showed significant differences according to Tukey's test $(P<0.05)$.

Among all dried samples without ultrasound application (AIR), the highestlossesin AAC, VEC, and TPC were observedin samples dried at $15^{\circ} \mathrm{C}$, probably due to higher bioactive compounds degradation at higher temperatures. Similar results were obtained by Santacatalina et al.:4 TPC exhibited slight but significantly higher $(P<0.05)$ losses in apple dried samples at $10^{\circ} \mathrm{C}(40 \%)$ than at $0^{\circ} \mathrm{C}$ $(36 \%)$. In hot-air drying of kiwifruit, higher AAC losses were also observed with the increase of the drying temperature by Kaya et al. ${ }^{33}$ at $35-65{ }^{\circ} \mathrm{C}(49-88 \%$ losses $)$.

Samples dried at 5,10 , and $15^{\circ} \mathrm{C}$ with ultrasound application

(AIR + US) exhibited AAC, VEC and TPClosses of $6-15 \%, 47-65 \%$ and $30-50 \%$, respectively, compared with the fresh sample. Thus, also in this case, the VEC losses were higher than AAC losses in dried samples with ultrasound application at 5,10 and $15^{\circ} \mathrm{C}$. Furthermore, the TPC losses were also higher than the AAC losses in these samples.

In the case of samples dried at 5 and $10^{\circ} \mathrm{C}$ with ultrasound application (AIR + US), the VEC and the TPC losses were significantly higher $(P<0.05)$ than the corresponding dried samples without ultrasound application (AIR). This behavior was also observed by Santacatalina et al. ${ }^{4}$ in TPC when drying apple cubes at temperatures of 0,5 , and $10^{\circ} \mathrm{C}$ with and without ultrasound application

(at $20.5 \mathrm{~kW} \mathrm{~m}^{-3}$ ). According to this study, this greater degradation could be linked to the structural damage of cells brought about by ultrasound. The mechanical stress linked to ultrasonic wave propagation could therefore aid the release of oxidative enzymes and intra-cellular compounds into the solvent, contributing to the degradation of polyphenol in a similarway to freezing. In hot-air drying, high degradation of VEC ${ }^{16,35}$ and TPC ${ }^{26,36}$ were also reported by different studies when ultrasound was applied.

However, samples dried at $15^{\circ} \mathrm{C}$ with ultrasound application

(AIR + US) exhibited significantly lower $(P<0.05)$ losses of AAC (as well as samples dried at 5 and $10^{\circ} \mathrm{C}$ ), VEC, and TPC, than the corresponding dried samples without ultrasound application (AIR). Itseems thatultrasound applicationled to abetterretention ofTPCinthese cases, probablydue to the shortening ofthedrying time, which reduces the thermal exposure of the samples and, consequently, the bioactive compound degradation. According to Moreno et al., ${ }^{37}$ the application of ultrasound can activate a response mechanism in the tissue that induces the formation of new phenolic compounds, not only through the combination of existing compounds but also via the activation of secondary metabolic pathways. Furthermore, the fact that the ultrasonic treatment produced a possible inactivation of oxidative enzymes must also be considered. Similar effects in AAC, ${ }^{38} \mathrm{VEC}^{16,35}$ and
$\mathrm{TPC}^{26}$ were also reported in the bibliography of hot-air drying when ultrasound was applied.

\section{Antioxidant activity}

Antioxidant activity (AA) in kiwifruit samples was determined using the FRAP, CUPRAC, and ABTS methods to evaluate the effects of drying temperature and ultrasound application. In each AA method used, the measurement is based on a single electron transfer, but the antioxidants present in the medium maybehydrophilic or lipophilic in nature and this will aid the reaction to a greater or lesser extent. It should be noted that, as each method is based on a different chemical system and / or reaction, the AA figures clearly varied for each sample extract, depending on the method. ${ }^{39}$ However, the results of AA according to FRAP, CUPRAC, and ABTS correlated highly with each other, the correlation coefficientbeing higher than 0.89 .

The AA of the fresh sample, according to the FRAP, CUPRAC, and ABTS methods, was $42 \pm 3,26 \pm 1$ and $34 \pm 2 \mathrm{mg}$ Trolox equivalent g d.m. ${ }^{-1}$, respectively. Similar values of AA, according to the FRAP method, were reported by Pal et al. ${ }^{31}$ in fresh kiwifruit of the Hayward cultivar at three different fruit-harvesting months (38-50 mg Troloxequivalent g d.m. ${ }^{-1}$ ). Similar values of $A A$, according to the CUPRAC and ABTS methods, were reported by Leontowicz et al. ${ }^{40}$ in kiwifruit ( $22 \pm 3$ and $41 \pm 4 \mathrm{mg}$ Trolox equivalent g d.m. ${ }^{-1}$, respectively).

Loss (\%) (Eqn (6)) of the AA, according to the FRAP, CUPRAC and ABTS methods, in the kiwifruit samples after drying at 5 , 10 , and $15^{\circ} \mathrm{C}$ without (AIR) and with ultrasound application (AIR + US), compared with the fresh sample, are shown in Fig. 5. In general, when samples were dried without ultrasound assistance (AIR), the AA losses were higher after drying at $15^{\circ} \mathrm{C}$ than at $5^{\circ} \mathrm{C}$, as was also observed in bioactive compounds losses, which might be related to higher bioactive compounds degradation at higher temperatures. Santacatalina et al. ${ }^{4}$ also reported significantly higher $(P<0.05)$ AA Loss $(\%)$ according to the CUPRAC method in apple-dried samples at $10^{\circ} \mathrm{C}(21 \%)$ than at $0^{\circ} \mathrm{C}(18 \%)$.

Antioxidant activity Loss (\%) were significantly higher $(P<0.05)$ in samples dried at 5 and $10^{\circ} \mathrm{C}$ with ultrasound application (AIR + US) than the corresponding dried samples without ultrasound application (AIR). As was mentioned above, this greater degradation could be linked to the structural damage to cells brought about by ultrasound. Santacatalina et al. ${ }^{4}$ also reported lower AA according to ABTS and CUPRAC methodswhendrying applecubes at lowtemperatures of 0,5 and $10^{\circ} \mathrm{C}$ withoutand with ultrasound 

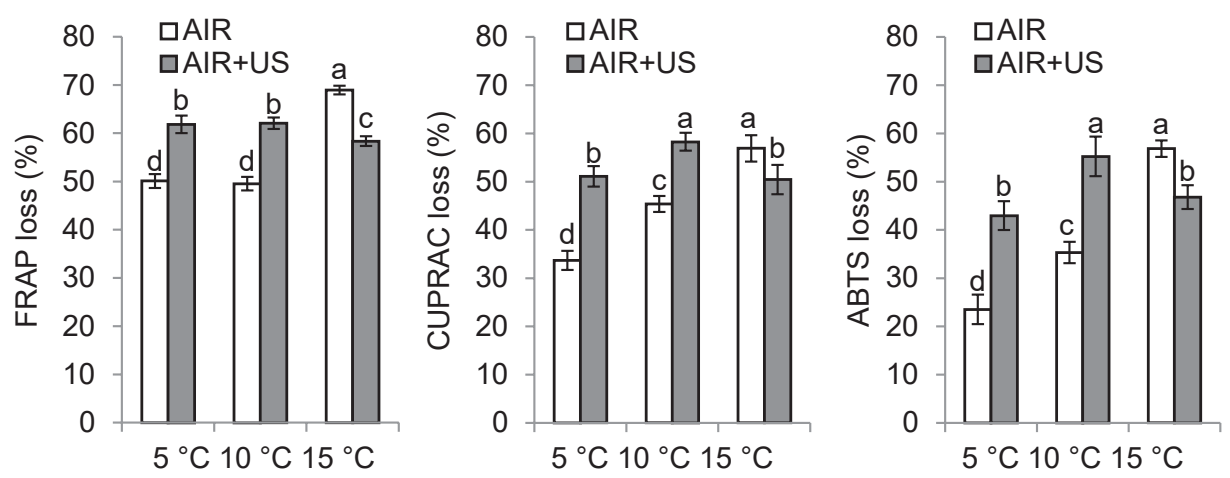

Figure 5. Kiwifruit losses (\%) of antioxidant activity (AA), according to FRAP, CUPRAC and ABTS methods, after drying at 5,10 and $15^{\circ} \mathrm{C}$ without (AIR, white bars) and with $20.5 \mathrm{~kW} \mathrm{~m}^{-3}$ of acoustic assistance (AIR + US, grey bars). Average values \pm standard deviations. Means with different letters for AA losses, according to FRAP, CUPRAC or ABTS methods, showed significant differences according to Tukey's test $(P<0.05)$.

application (20.5 $\left.\mathrm{kW} \mathrm{m}^{-3}\right)$. In hot air drying, Do Nascimento et al. ${ }^{26}$ also observed lower AA (according to FRAP method) in dried passion-fruit peel (at 60 and $70{ }^{\circ} \mathrm{C}$ and $1 \mathrm{~m} \mathrm{~s}^{-1}$ ) with ultrasound application $\left(30.8 \mathrm{~kW} \mathrm{~m}^{-3}\right)$ than in corresponding samples without ultrasound application.

However, significantly lower $(P<0.05)$ AA losses were observed

in samples dried at $15^{\circ} \mathrm{C}$ with ultrasound application (AIR + US) than the corresponding dried samples without ultrasound application (AIR). It seems that ultrasound application leads to a better retention of AA in these cases, as was mentioned with regard to bioactive compounds. This better retention of AA was probably due to the shortening of the drying time, which reduces the thermal exposure of the samples and, consequently, the antioxidant activity degradation; or it might be related to a response mechanism of the tissue activated by ultrasound as reported by Moreno etal. ${ }^{37}$ These results therefore correlated better with the retention of bioactive compounds mentioned above when ultrasound was applied at $15^{\circ} \mathrm{C}$. In hot air, significantly higher $(P<0.05)$ AA(FRAP method) was observed in passion fruit peel dried at 40 and $50^{\circ} \mathrm{C}$ and $1 \mathrm{~m} \mathrm{~s}^{-1}$ with ultrasound application (at $30.8 \mathrm{~kW} \mathrm{~m}^{-3}$ ) than without ultrasound application. ${ }^{26}$

\section{CONCLUSIONS}

The effects of acoustic assistance on a low-temperature drying process of kiwifruit have been studied. The intensification of the drying process was achieved by applying power ultrasound. Reductions of $55-65 \%$ in drying time were observed. A diffusion model considering both internal and external resistance satisfactorily simulated the drying kinetics (MRE $=3.3 \pm 1.3 \%$, var $=99.7 \pm 0.2 \%$ ). The acoustic energy caused an increment in the effective diffusion coefficient $D_{e}$ and the external mass transfer coefficient $h_{m}$ by up to $120-175 \%$ and $103-231 \%$, respectively, which indicates an improvement in the drying rate caused by the application of power ultrasound. Significantly lower $(P<0.05)$ bioactive compound content (AAC, VEC and TPC , $14-54 \%$ of loss) and AA (23-69\% of loss) were observed in all dried kiwifruit samples compared with the fresh sample. Ultrasound applied during drying at 5 and $10^{\circ} \mathrm{C}$ promoted higher $(P<0.05)$ biocompound losses (VEC and TPC) and AA $(35-65 \%$ and $43-62 \%$, respectively) than those in corresponding samples without ultrasound application (14-43\% and $23-50 \%$, respectively). However, when drying was carried out at $15^{\circ} \mathrm{C}$, ultrasound contributed to the preservation of these biocompounds and antioxidant activity ( $30-47 \%$ and $47-58 \%$, respectively) better
$(P<0.05)$ than in samples obtained without using ultrasound (39-54\% and $57-69 \%$, respectively). Thus, the use of ultrasound when drying at $15^{\circ} \mathrm{C}$ allowed the shortest drying time and better maintained biocompound content and antioxidant activity.

\section{NOMENCLATURE}

\begin{tabular}{|c|c|}
\hline$D_{e}$ & Effective water diffusion coefficient $\left(m^{2} s^{-1}\right)$ \\
\hline$D_{0}$ & Parameter in the effective diffusivity model $\left(\mathrm{m}^{2} \mathrm{~s}^{-1}\right)$ \\
\hline$E_{a}$ & Activation energy $\left(\mathrm{kJ} \mathrm{mol}^{-1}\right)$ \\
\hline$h_{m}$ & External mass transfer coefficient $\left(\mathrm{kg}\right.$ water $\left.\mathrm{m}^{-2} \mathrm{~s}^{-1}\right)$ \\
\hline L & Length $(\mathrm{m})$ \\
\hline$n$ & Number of experimental data \\
\hline MRE & Mean relative error $(\%)$ \\
\hline $\mathrm{R}_{x}$ & $\begin{array}{l}\text { Universal gas.constant }\left(\mathrm{Jmol}^{-1} \mathrm{~K}^{-1} \text { ) }\right. \\
\text { Standard deviation (sample) }\end{array}$ \\
\hline$S_{y x}$ & Standard deviation (estimation) \\
\hline$T$ & Temperature $\left({ }^{\circ} \mathrm{C}\right)$ \\
\hline$t$ & Time $(\mathrm{h})$ \\
\hline var & Percentage of explained variance (\%) \\
\hline w & Moisture content (kg kg d.m..$\left.^{-1}\right)$ \\
\hline$x, y, z$ & Spatial coordinates $(\mathrm{m})$ \\
\hline$\square d m$ & Dry matter density (kg d.m. $\mathrm{m}^{-3}$ ) \\
\hline$\square$ & Relative humidity \\
\hline \multicolumn{2}{|c|}{ Subscripts } \\
\hline 0 & initial \\
\hline$\infty$ & drying air \\
\hline cal & calculated \\
\hline$e$ & equilibrium at the surface \\
\hline \multicolumn{2}{|c|}{ Abbreviations } \\
\hline AIR & Convective air experiments \\
\hline $\begin{array}{l}\text { AIR + US } \\
\text { MRE }\end{array}$ & $\begin{array}{l}\text { Convective air experiments assisted by ultrasound } \\
\text { Mean relative error }\end{array}$ \\
\hline AAC & Ascorbic acid content \\
\hline VEC & Vitamin E content \\
\hline TPC & Total polyphenol content \\
\hline AA & Antioxidant activity \\
\hline var & Percentage of explained variance \\
\hline
\end{tabular}

\section{ACKNOWLEDGEMENTS}

The authors would like to acknowledge the financial support of the National Institute of Research and Agro-Food Technology 
(INIA) and co-financed with ERDF funds (RTA2015-00060-C04-03 and RTA2015-00060-C04-02 projects) and the Spanish Government (MINECO) for the BES-2013-064131 fellowship.

\section{REFERENCES}

1 Soquetta MB, Stefanello FS, Huerta KM, Monteiro SS, da Rosa CS and Terra NN, Characterization of physiochemical and microbiological properties, and bioactive compounds, of flour made from the skin and bagasse of kiwi fruit (Actinidia deliciosa). Food Chem 199 (Suppl. C):471-478 (2016).

2 Du G, Li M, Ma F and Liang D, Antioxidant capacity and the relationship with polyphenol and vitamin $\mathrm{C}$ in Actinidia fruits. Food Chem 113:557-562 (2009).

3 Fernández-Sestelo A, de Saá RS, Pérez-Lamela C, Torrado-Agrasar A Rúa ML and Pastrana-Castro L, Overall quality properties in pressurized kiwi purée: microbial, physicochemical, nutritive and sensory tests during refrigerated storage. Innov Food SciEmerg Technol (Suppl. C) 20:64-72 (2013).

4 Santacatalina J, Rodríguez O, Simal S, Cárcel J, Mulet A and García-Pérez J, Ultrasonically enhanced low-temperature drying of apple: influence on drying kinetics and antioxidant potential. J Food Eng 138:35-44 (2014).

5 Vallespir F, Cárcel JA, Marra F, Eim VS and Simal S, Improvement of mass transfer by freezing pre-treatment and ultrasound application on the convective drying of beetroot (Beta vulgaris L.). Food Bioproc Tech 11:72-83 (2018).

6 Ozuna C, Cárcel JA, Walde PM and Garcia-Perez JV, Low-temperature drying of salted cod (Gadus morhua) assisted by high power ultrasound: kinetics and physical properties. Innov Food Sci Emerg Technol (Suppl. C) 23:146-155 (2014).

7 Rodríguez Ó, Santacatalina JV, Simal S, Garcia-Perez JV, Femenia A and Rosselló C, Influence of power ultrasound application on drying kinetics of apple and its antioxidant and microstructural properties. J Food Eng 129:21-29 (2014)

8 García-Pérez JV, Cárcel JA, Riera E, Rosselló C and Mulet A, Intensification of low-temperature drying by using ultrasound. Drying Technol 30:1199-1208 (2012).

9 CárcelJA, García-PérezJV, Riera E, Rosselló C and MuletA, Ultrasonically assisted drying, in Ultrasound in Food Processing, ed. by Mar Villamiel, Jose V. Garcia-Perez, Antonia Montilla, Juan A. Carcel, Jose Benedito, John Wiley \& Sons, Ltd, New York, pp. 371-391 (2017).

10 García-Pérez JV, Carcel JA, Mulet A, Riera E and Gallego-Juarez JA, Ultrasonic drying for food preservation, in Power Ultrasonics, ed. by, Juan A Gallego-Juárez and Karl F Graff, Woodhead Publishing, Oxford, pp. 875-910 (2015)

11 Association of Analytical Communities (AOAC), Moisture inDriedFruits, 16 th edn. AOAC, Rockville, MD (2006).

12 Rodríguez Ó, Eim VS, Simal S, Femenia A and Rosselló C, Validation of a diffusion model using moisture profiles measured by means of TD-NMR in apples (Malus domestica). FoodBioproc Tech 6:542-552 (2013).

13 Moraga G, Martínez-Navarrete N and Chiralt A, Water sorption isotherms and phase transitions in kiwifruit. J Food Eng 72:147-156 (2006).

14 Lagarias JC, Reeds JA, WrightMHandWrightPE, Convergence properties of the Nelder-Mead simplex method in low dimensions. SIAM J Optimiz 9:112-147 (1998).

15 Salkic' M, Keran H and Jašic' M, Determination of L-ascorbic acid in pharmaceutical preparations using direct ultraviolet spectrophotometry. Agric Conspec Sci 74:263-268 (2009).

16 Fernandes FAN, Rodrigues S, Cárcel JA and García-Pérez JV, Ultrasound-assisted air-drying of apple (Malus domestica L.) and its effects on the vitamin of the dried product. Food Bioproc Tech 8:1503-1511 (2015).

17 Heredia JB and Cisneros-Zevallos L, The effects of exogenous ethylene and methyljasmonate on the accumulation of phenolic antioxidants in selected whole and wounded fresh produce. Food Chem 115:1500-1508 (2009).

18 Singleton VL and Rossi JA, Colorimetry of total phenolics with phosphomolybdic-phosphotungstic acid reagents. Am J Enol Vitic 16:144-158 (1965).

19 Benzie IF and Strain JJ, The ferric reducing ability of plasma (FRAP) as a measure of 'antioxidant power': the FRAP assay. Anal Biochem 239:70-76 (1996).
20 Apak R, Güçlü K, Özyürek M and Karademir SE, Novel total antioxidant capacity index for dietary polyphenols and vitamins $\mathrm{C}$ and $\mathrm{E}$, using their cupricion reducing capability in the presence of neocuproine: CUPRAC method. JAgric Food Chem 52:7970-7981(2004).

21 ReR, PellegriniN, ProteggenteA, PannalaA, Yang MandRice-Evans C, Antioxidant activity applying an improved ABTS radical cation decolorizationassay. Free RadicalBioMed 26:1231-1237(1999).

22 Santacatalina JV, Soriano JR, Cárcel JA and Garcia-Perez JV, Influence of air velocity and temperature on ultrasonically assisted low temperature drying of eggplant. FoodBioprod Process 100(Part A):282-291 (2016).

23 Darıcı S and Ssen S, Experimental investigation of convective drying kinetics of kiwi under different conditions. Heat Mass Transfer 51:1167-1176 (2015).

24 García-Pérez JV, Rosselló C, Cárcel J, De la Fuente S and Mulet A eds, Effect of air temperature on convective drying assisted by high power ultrasound, in Defect and Diffusion Forum. Trans Tech Publications, Switzerland,(2006).

25 Gamboa-Santos J, Montilla A, Cárcel JA, Villamiel M and Garcia-Perez $\mathrm{JV}$, Air-borne ultrasound application in the convective drying of strawberry. J Food Eng 128:132-139 (2014).

26 Do Nascimento EMGC, Mulet A, Ascheri JLR, de Carvalho CWP and Cárcel JA, Effects of high-intensity ultrasound on drying kinetics and antioxidant properties of passion fruit peel. J Food Eng 170:108-118 (2016).

27 García-Pérez JV, Ortuño C, Puig A, Cárcel JA and Perez-Munuera I, Enhancement of water transport and microstructural changes induced by high-intensity ultrasound application on orange peel drying. Food Bioproc Tech 5:2256-2265 (2012).

28 Santacatalina JV, Contreras M, Simal S, Cárcel JA and Garcia-Perez JV, Impact of applied ultrasonic power on the low temperature drying of apple. Ultrason Sonochem (Suppl. C) 28:100-109(2016).

29 Rodriguez O, Eim V, Rossello C, Femenia A, Carcel JA and Simal S, Application of power ultrasound on the convective drying of fruits and vegetables: effects on quality. J Sci Food Agric 98:1660-1673 (2018).

30 Sivakumaran S, Huffman L, Sivakumaran S and Drummond L, The nutritional composition of Zespri ${ }^{\circledR}$ SunGold kiwifruit and Zespri ${ }^{\circledR}$ sweet green kiwifruit. Food Chem (Suppl. C) 238:195-202 (2018).

31 PalRS, KumarVA, Arora S, Sharma A, KumarVand Agrawal S, Physicochemical and antioxidant properties of kiwifruit as a function of cultivar and fruit harvested month. Braz Arch Biol Technol 58:262-271 (2015).

32 Ball GF, Vitamins in Foods: Analysis, Bioavailability, and Stability. CRC Press, Taylor \& Francis Group, Boca Raton, FL, USA, (2005).

33 Kaya A, Aydın O and Kolaylı S, Effect of different drying conditions on the vitamin C (ascorbic acid) content of Hayward kiwifruits (Actinidia deliciosaPlanch). FoodBioprodProcess 88:165-173(2010).

34 Izli N, Izli G and Taskin O, Drying kinetics, colour, total phenolic content and antioxidant capacity properties of kiwi dried by different methods. J Food Meas Charact 11:64-74 (2017).

35 Fernandes FAN, Rodrigues S, García-Pérez JV and Cárcel JA, Effects of ultrasound-assisted air-drying on vitamins and carotenoids of cherry tomatoes. Drying Technol 34:986-996 (2016).

36 Cruz L, Clemente G, Mulet A, Ahmad-Qasem MH, Barrajón-Catalán E and García-Pérez JV, Air-borne ultrasonic application in the drying of grape skin: kinetic and quality considerations. J Food Eng 168:251-258 (2016).

37 Moreno C, Brines C, Mulet A, Rosselló C and Cárcel JA, Antioxidant potential of atmospheric freeze-dried apples as affected by ultrasound application and sample surface. Drying Technol 35:957-968 (2017).

38 Szadzińska J, Łechtańska J, Kowalski SJ and Stasiak M, The effect of high power airborne ultrasound and microwaves on convective drying effectiveness and quality of green pepper. Ultrason Sonochem (Suppl. C) 34:531-539 (2017).

39 González-Centeno MR, Jourdes M, Femenia A, Simal S, Rosselló C and Teissedre P-L, Proanthocyanidin composition and antioxidant potential of the stem winemaking byproducts from 10 different grape varieties (Vitis viniferaL.). JAgric Food Chem 60:11850-11858 (2012).

40 Leontowicz H, Leontowicz M, Latocha P, Jesion I, Park Y-S, Katrich E et al., Bioactivity and nutritional properties of hardy kiwi fruit Actinidia arguta in comparison with Actinidia deliciosa 'Hayward' and Actinidia eriantha 'Bidan'. Food Chem 196:281-291 (Suppl. C) (2016). 